\title{
Motivation Moderates the Effect of Internal Control Systems and Budgetary Participation on Individual Performance
}

\author{
Mertyani Sari Dewi* \\ Sekolah Tinggi Ilmu Ekonomi Satya Dharma
}

\section{A R T I C L E I N F O}

Article history:

Received 01 December 2019

Received in revised form

31 December 2019

Accepted 15 January 2020

Available online 26

February 2020

Keywords:

Control Internal, Budgetary,

Motivation, Performance

\section{A B S T R A C. T}

Individual performance is the level of work performed by individuals in the organization that is used as a basis for evaluating the organization. This study aimed at obtaining empirical evidence regarding the influence of the internal control system and participation in preparing budgets on individual performance with motivation as moderating. This study was conducted at 30 Bangli District Regional Organizations (OPD) collected through questionnaires. The samples were 60 people through non-probability sampling. This study was tested using a structural equation model (Structural Equation Modeling-SEM) based on variance or Component-based SEM with a Smart-PLS 3.0 analysis tool. The result showed that the internal control system has a significant positive effect on individual performance. Budgeting participation has a positive effect but not significant on individual performance. The result showed that work motivation can strengthen the internal control system and participation in compiling budgets on individual performance.

\footnotetext{
* Corresponding author.

E-mail addresses: mertyanisaridewi@gmail.com (Mertyani Sari Dewi)
} 


\section{Introduction}

Government performance is often a concern because performance is an important indicator in the success of a government (Harsasto, 2013). The phenomenon of performance in local government, one of which is in Bangli Regency. Based on the results of the examination of the Supreme Audit Agency (BPK) on the representative of Bali Province in Bangli Regency, a disclaimer was given (not giving an opinion) on the 2013 Local Government Financial Report (LKPD). This opinion was given because the BPK found mismanagement of assets, there was no evidence transactions and weaknesses in the government's internal control system. Furthermore, Bangli got a disclaimer opinion because there were figures that could not be trusted by the BPK, namely on the cash side that exceeded the tolerance limit and there were errors in the leveling of assets and management of assets where the numbers on the balance sheet were not accompanied by supporting evidence

Results of BPK's audit of LKPD for the 2014 fiscal year, Bangli Regency obtained a Fair opinion with an Exception (WDP). This opinion increased from the one received by Bangli Regency in the previous year. In the Bangli Regency LKPD in the fiscal year of 2014 the BPK found that the treasury in the treasury was missing, there were assets that did not match the acquisition value and there were weaknesses in the government's internal control system. Then in the 2015 Fiscal Year LKPD, Bangli Regency still obtained WDP opinion because the BPK still found weaknesses in the government's internal control system.

Furthermore, based on the examination of LKPD Fiscal Year 2016 - 2018, Bangli Regency was given a Fair Opinion without Exception (WTP). This opinion has increased from the previous 5 years. Although Bangli Regency won the WTP opinion, the BPK still found weaknesses in the internal control system in the preparation of financial reports and non-compliance with applicable laws and regulations such as inadequate asset administration, inadequate tax revenue management, budgeting for employee expenditure, goods and services expenditure, capital expenditure is not in accordance with the provisions, and management of grant spending is inadequate. (www.denpasar.bpk.go.id).

The findings obtained by BPK reflect that there are still weaknesses in the performance of the Bangli Regency government. Some weaknesses that were found from the BPK's submission of audit results related to the evaluation and evaluation of the performance of government agencies' performance were the reasons for the government's optimal implementation. Nasir and Oktari (2013) stated that the need to measure the performance accountability side is in the aspect of activity in the environment of government agencies, one of which is in terms of individual performance.

The findings made by BPK suggest that the performance of the Bangli Regency government is still slow. The government is not yet optimal because there are still weaknesses that can be seen from the results of the evaluation and evaluation of performance accountability of government agencies that were previously submitted by BPK. Nasir and Oktari (2013), stated that activities in the environment of government agencies need to be measured in terms of performance accountability, one of which is in terms of individual performance. Individual performance is a measure that can be used to determine the comparison of the results of the implementation of the duties of employees or government officials, the responsibilities given by the organization in a certain period, and can relatively be used to measure work performance or organizational performance (Panggesto, 2014). So individual performance is a description of the level of achievement of goals or objectives as a translation of the vision, mission and strategy of local government agencies that indicate the level of success or failure of the implementation of activities in accordance with the main tasks and functions of the government apparatus.

Government internal control systems are very important in the sustainability of a government agency (Adewale, 2014). Every government agency should have a control system that can minimize existing risks (Saleba, 2014). With the existence of internal control, the entire process of audit activities, review, evaluation, monitoring, and other supervisory activities of the organization in order to provide adequate confidence that the activities have been carried out in accordance with established benchmarks (Dewi, 2015). Research conducted by Putri (2013) in the Padang Regional Government Work Unit (SKPD), research conducted by Tresnawati (2012) at the Bandung City Revenue Service and Trihapsoro (2015) on the Boyolali District SKPD conducted a study of the influence of the government's internal control system on the performance. These researchers found the same results, the government's internal control system had a positive effect on performance. While the research conducted by Shodiq (2001), Boritz and Jee (2007) and Santoso (2016) showed different results, this researcher found that the government's internal control system had no effect on performance.

The performance achieved by an organization is basically the achievements of the members of the organization itself, starting from the top level to the bottom level. In order to realize good governance, the government continues to make various efforts to improve performance, one of which is by improving the overall state administration system (Dewi, 2015). The use of budget is a concept that is often used to see 
performance. The application of performance-based budgeting to government agencies in Indonesia was announced through the enactment of Law No. 17 of 2003 concerning State Finances and was implemented in stages starting in the 2005 fiscal year.

Budgeting is an important and complex activity, so that a budget is right on target and in accordance with its objectives, it requires good cooperation between subordinates and superiors in preparing the budget. Budgeting participation is the best method in preparing the budget, because all components in the organization are involved in budgeting (Yanti, 2016). The budgeting process is an important activity, because the budget will have a functional and dysfunctional impact on the attitudes and behavior of the members of the organization involved in the preparation process. To prevent dysfunctional impacts by providing subordinates in this case employees or employees to participate in the budgeting process (Silmilian, 2013). Employees who are given the authority to participate are expected to provide good results in their participation in preparing the budget. Employee participation in determining organizational goals to be able to encourage organizational effectiveness to be better and able to minimize conflicts or problems that occur between individual goals with organizational goals. With the participation of individuals in the preparation of the budget is expected to motivate these individuals to achieve budget goals so that it will have an impact on improving individual performance.

Research conducted by Ferawati (2011), Utama (2013) and Saraswati (2015) concerning the effect of budgeting participation on performance found that budgetary participation had a positive effect on performance. However, different results were found from research conducted by Bryan and Locke (1967), Nursidin (2008) and Medhayanti (2015) found that budgetary participation had no effect on performance.

The inconsistency of the results of research that has been done previously makes researchers want to test whether the government's internal control system and budgetary participation affect individual performance by adding work motivation as a moderating variable. By using contingency theory, work motivation is able to act as a moderating variable in the relationship between government internal control systems and budgetary participation in individual performance. Wiguna (2016) states the need for research using a contingency approach because it can be used to test external factors that affect a relationship. Wijaya, et al. (2016) states that motivation provides a positive impact on internal control systems and improves performance. This means that motivation can moderate the effect of the government's internal control system on performance. Then research conducted by Dina (2014) that examined the effect of budgetary participation on performance with work motivation as a moderating variable found that motivation moderates the effect of budgeting participation on performance. In this study using a contingency approach using moderating variables, namely work motivation supported by research conducted by Wijaya et al. (2016) and Dina (2014) who both used work motivation as a moderating variable in the effect of the government's internal control system and budgetary participation on performance.

\section{Methods}

This research is located in all DPOs in Bangli Regency. This location was chosen because researchers were interested in BPK-RI's opinion on LKPD of the Bangli Regency Government which received a disclaimer opinion in 2013, WDP opinion in 2014-2015 and WTP opinion in 2016 - 2018. The time of the study was 2019. The research was conducted in OPD which is in Bangli Regency which amounts to 30 OPD. The scope of this study is limited to the role of work motivation as a moderator that influences the government's internal control system (SPI) and participation in preparing budgets on individual performance.

This study uses government officials who worked on 30 OPD in Bangli Regency as the study population. The sampling technique used is non-probability method with saturated sampling technique that is determining the sample that all members of the population are used as samples. Respondents in this study amounted to 60 respondents, consisting of PPK employees (Financial Administration Officers) and Treasurer OPD in the Bangli District Government Environment. The data that has been collected is analyzed by (Structural Equation Modeling-SEM) based on variance or Component based SEM, which is famously called Partial Least Square (PLS) Visual version 3.0

\section{Result And Discussion}

In this study there are four constructs consisting of 2 exogenous variables, namely the Government Internal Control System which is measured by sixteen indicators. Second, Budgetary Participation as measured by six indicators. The endogenous variables in this study are Individual 
Performance as measured by five indicators. The moderating variable in this study is motivation which is measured by six indicators.

The construct is said to have high reliability if the Composite Reliability value is above 0.70 and the Cronbachs Alpha value is above 0.60 (Ghozali, 2008). Table 1 presents the Composite Reliability and Cronbachs Alpha values for all variables.

Table 1. Composite Reliability dan Croncbach Alpha Value

\begin{tabular}{lll}
\hline & Cronbach's Alpha & Composite Reliability \\
\hline Individual Performance & 0.840 & 0.887 \\
\hline Moderating Effect 1 & 1.000 & 1.000 \\
\hline Moderating Effect 2 & 1.000 & 1.000 \\
\hline Budgeting Participation & 0.919 & 0.937 \\
\hline Government Internal Control System & 0.952 & 0.958 \\
\hline
\end{tabular}

Source: Processed data

In Table 1 above, it shows that all constructs in this study produce Composite Reliability values above 0.70 and Cronbachs Alpha values above 0.60. The lowest value of Composite Reliability is in the Individual Performance construct with a value of 0.840 and Cronbachs Alpha is in the Individual Performance construct with a value of 0.887 . It can be concluded that the construct in this study is reliable.

To strengthen the valid statement of the construct of this study, researchers also used the Average Variance Extracted (AVE) method. a good construct requires the AVE value to be above 0.50. AVE test results are described as follows:

Table 2. Average Variance Extracted (AVE) Value

\begin{tabular}{ll}
\hline Individual Performance & 0.613 \\
\hline Moderating Effect 1 & 1.000 \\
\hline Moderating Effect 2 & 1.000 \\
\hline Budgeting Participation & 0.712 \\
\hline Government Internal Control System & 0.601 \\
\hline
\end{tabular}

Source: Processed data

Table 2 gives AVE values above 0.5 for all constructs contained in the research model. The lowest value of AVE is 0.601 in the SPI construct, so it can be concluded that the construct in this study is valid.

In assessing the model with PLS it starts by looking at the R-square for each latent dependent variable (Ghozali, 2013). Table 3 is the result of R-square estimation using Smart PLS.

Table 3. R-Square Value

\begin{tabular}{lll}
\hline & R Square & R Square Adjusted \\
\hline Individual Performance & 0.893 & 0.883 \\
\hline
\end{tabular}

Source: Processed data

Based on the determination coefficient data above it is known that the R-Square value of Individual Performance of 0.893 the magnitude of the R-Square value of 0.893 equals $89.3 \%$ can be explained by three construct variables.

The significance of the endogenous indicators can be seen from the T-statistic value. If $t$-value $>t$ Table, all indicators can be said to be significant in measuring endogenous constructs. The results of testing with the bootstrapping method of SEM PLS analysis are shown in Figure 1. 


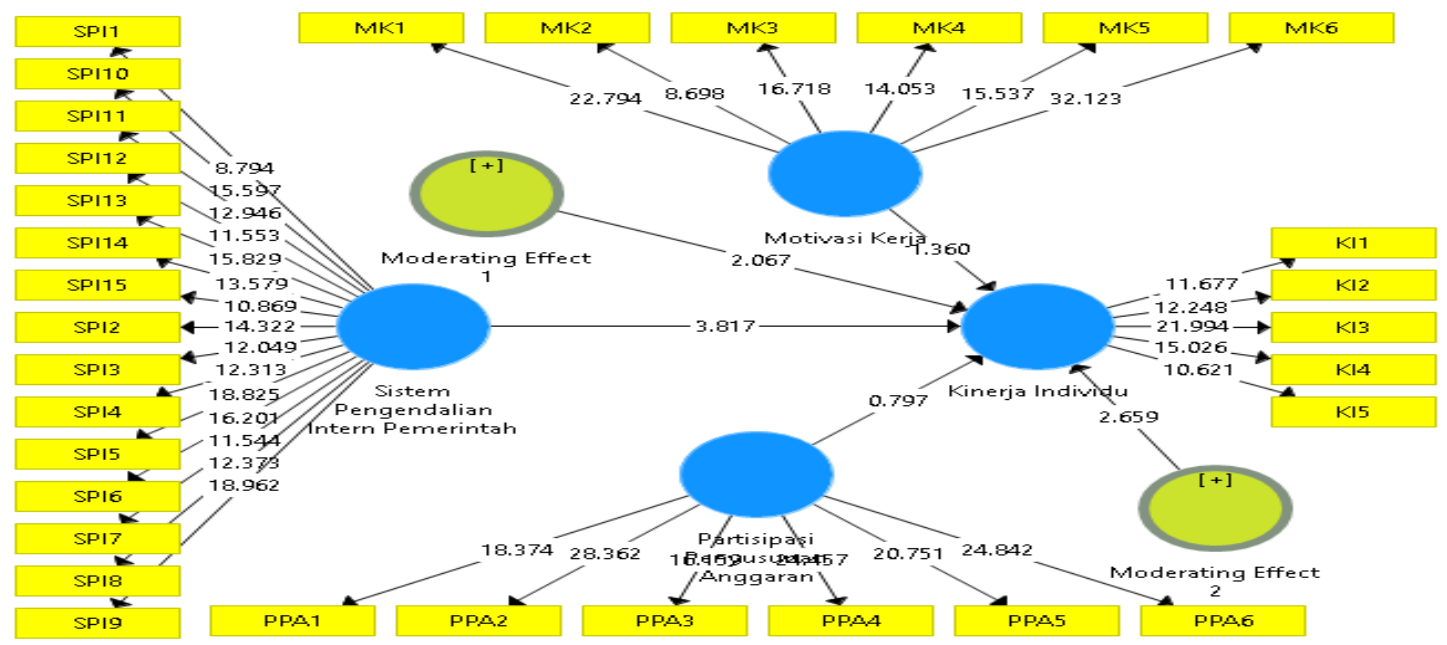

Figure 1. Bootstraping

The basis used in testing hypotheses is the value contained in the output forinner weight. Table 4 provides estimated outputs for testing structural models.

Table 4. Result for Inner Weight

\begin{tabular}{|c|c|c|c|c|c|}
\hline & $\begin{array}{l}\text { Original } \\
\text { Sample (0) }\end{array}$ & $\begin{array}{l}\text { Sample } \\
\text { Mean } \\
(\mathrm{M})\end{array}$ & $\begin{array}{l}\text { Standard } \\
\text { Deviation } \\
\text { (STDEV) }\end{array}$ & $\begin{array}{l}\text { T Statistics } \\
(\mid \mathrm{O} / \text { STDEV } \mid)\end{array}$ & $\begin{array}{l}\mathrm{P} \\
\text { Values }\end{array}$ \\
\hline $\begin{array}{lrl}\text { Moderating Effect } 1 & -> \\
\text { Individual Performance } & \\
\end{array}$ & -0.193 & -0.166 & 0.093 & 2.067 & 0.039 \\
\hline $\begin{array}{lrl}\text { Moderating Effect } 2 & -> \\
\text { Individual Performance } & \\
\end{array}$ & 0.251 & 0.226 & 0.094 & 2.659 & 0.008 \\
\hline $\begin{array}{l}\text { Budgeting Participation } \\
\text { Individual Performance }\end{array}$ & 0.164 & 0.157 & 0.205 & 0.797 & 0.426 \\
\hline $\begin{array}{l}\text { Government Internal Control } \\
\text { System } \rightarrow>\text { Individual } \\
\text { Performance }\end{array}$ & 0.538 & 0.551 & 0.141 & 3.817 & 0.000 \\
\hline
\end{tabular}

Source: Processed data

a. Effect of Internal Control Systems on Individual Performance.

The first hypothesis testing results show that the relationship of internal control systems to individual performance has a parameter coefficient of 0.538 with $t$ of 3.817 where the value is greater than t table (1.906). These results indicate that the government's internal control system has a positive and significant relationship to individual performance, which means that hypothesis 1 is accepted. This proves that the existence of an internal control system in accordance with the application of existing work rules will improve individual performance.

Putri (2013) states that a good internal control system in an organization is able to create a good overall process of activities, so that later it will provide a belief for individuals that the activities carried out have been carried out in accordance with established benchmarks. This study obtained the same results as the research conducted by Trihapsoro (2015) and Njeri (2014) which stated that the government's internal control system had a positive effect on individual performance.

b. Effects of Budgetary Participation on Individual Performance

The results of the second hypothesis testing show that the relationship between budgetary participation and individual performance has a parameter coefficient of 0.164 with $t$ of 0.797 where the value is smaller than $t$ table (1.906). These results indicate that budgetary participation has a positive and not significant relationship to individual performance, which means that hypothesis 2 is rejected. This means that the level of employee involvement is low in the budget preparation process.

Individual performance is indeed involved in the budgeting process but the involvement of an individual is limited to participating in the plan because as an obligation to participate but the 
involvement is not balanced by using creative ideas owned by an individual. Supposedly getting involved and working well will produce good performance. The results of this study support the research conducted by Andison and Augustine (2017), and Janah and Rahayu (2015). However, this study does not support the research that has been done by Ermawati (2012), and Aisyah, et al (2017).

\section{c. Effect of Work Motivation Moderating Government Internal Control Systems On Individual Performance.}

The output results show that the interaction coefficient value of the government's internal control system with work motivation of -0.193 with $t$ of 2.067 where the value is greater than $t$ table (1.906). Based on these data, work motivation moderates the government's internal control system on individual performance, which means hypothesis 3 is accepted. Positive and significant value of the coefficient of interaction between the government's internal control system and work motivation means that work motivation can strengthen the effect of the government's internal control system on individual performance. This means, with a good work motivation through a good government internal control system can affect individual performance.

Research conducted by Atmadja, et al. (2014) states that motivation has a significant influence on internal control systems. This indicates that motivation alone can influence internal auditors to work and provide useful statements for the effectiveness of internal control systems. This research is supported by research conducted by Wijaya, et al. (2016) which states that motivation provides a positive impact on internal control systems and improves performance. This means that motivation strengthens the influence of the government's internal control system on individual performance.

\section{d. Effect of Work Motivation Moderate Budgeting Participation On Individual Performance}

The output results show that the interaction coefficient value of budget participation with work motivation is 0.251 with $t$ equal to 2.659 where the value is greater than $t$ table (1.906). Based on these data, work motivation moderates the effect of budgetary participation on individual performance, which means hypothesis 4 is accepted. Positive and significant value of the interaction coefficient of budgeting participation with work motivation means that work motivation can strengthen the influence of budgetary participation on individual performance. This means, with the existence of work motivation through empowerment in anticipation of budgeting can affect maximum individual performance at government agencies.

High or low levels of employee motivation in carrying out the budgeting process can affect the performance of the employee. The higher the motivation of the employee, the more effective the performance of the employee in the budgeting process, because the high motivation possessed by an employee allows the employee to be better at participating in budgeting. The results of this study are in line with research conducted by Adiputra (2002), Becker and Green (1992) in Riyadi (1998) and Mia (1998) which state that work motivation has a significant effect in moderating the influence of budgetary participation on performance. Where motivation has a significant effect on the relationship between budgetary participation and performance

\section{Conclussion}

Based on the results of data analysis and discussion described in the previous chapter, it can be concluded that for the first direct test the results state that there is a significant positive influence between the internal control system and individual performance. The second test, the results state that participation in preparing a budget has a positive but not significant relationship to individual performance. In addition, testing with moderating variables obtained results including work motivation which moderates the effect of the internal control system on individual performance. Work motivation is a moderating effect of participation in preparing a budget on individual performance.

\section{Reference}

Adewale, Odunayo Hendry. (2014). Internal Control System: A Managerial Tool For Proper Accountability A Case Study of Nigeria Customs Service. European Scientific Journal. 10(13). Retrieved from : https://eujournal.org/index.php/esj/article/view/3353/3117

Adiputra, I Made Pradana. (2002). Pengaruh Motivasi dan Pelimpahan Wewenang sebagai Variabel Moderating Terhadap Hubungan Antara Partisipasi Penyusunan Anggaran dan Kinerja Manajerial 
(Studi Empiris Pada Hotel Bintang Di Bali). Tesis. Universitas Diponegoro Semarang. Retri eved from : https://ejournal.undip.ac.id/index.php/jbs/article/view/14291

Agustina, Dewi. (2013). Pengaruh Partisipasi Penyusunan Anggaran Terhadap Kinerja Manajerial Dengan Gaya Kepemimpinan Dan Motivasi Sebagai Variabel Moderating (Survey di Perusahaan Daerah Air Minum (PDAM) Se Karesidenan Surakarta). Artikel Publikasi Ilmiah. Universitas Muhammadiyah Surakarta. Retrieved from : http://eprints.ums.ac.id/id/eprint/25749

Aisyah Siti Nur, Sutisno, Erwin Saraswati. (2017). The Effect of Participatory Budgets on The Performance of School (Studies in Smk Sumbawa). Journal of Accounting and Business Education, 1 (2), March 2017. DOI : http://dx.doi.org/10.26675/jabe.v1i2.8492

Atmadja, Ananta Wikrama Tungga, Ni Kadek Novianti \& Gede Adi Yuniarta. (2014). Pengaruh Independensi, Motivasi, Pengalaman Kerjadan Keahlian Profesional Badan Pengawas Terhadap Efektivitas Penerapan Pengendalian Intern Lembaga Perkreditan Desa (LPD) di KecamatanKuta Selatan Kabupaten Badung. Jurnal Akuntansi Universitas Pendidikan Ganesha. 2(1). DOI: http://dx.doi.org/10.23887/jimat.v2i1.3425

Boritz, E., dan Jee H. L. (2007). Control Weaknesses, IT Governance and Firm Performance. Paper. University of Waterloo.

Bryan. J, dan E. A. Locke. 1967, Goal Setting as a Means of Increasing Motivation, The of Applied Psycology, pp: 274-277.

Dewi, Mertyani Sari. 2015. Faktor-faktor yang Memengaruhi Kinerja Pemerintah Daerah (Studi Empiris pada Satuan Kerja Perangat Daerah Kabupaten Bangli). Skripsi. Universitas Pendidikan Ganesha. DOI: http://dx.doi.org/10.23887/jimat.v3i1.5317

Dina, Gemelly Rama. 2014. Pengaruh Partisipasi Penyusunan Anggaran Terhadap Kinerja Manajerial dengan Motivasi Kerja Sebagai Variabel Moderating pada Bank Negara Indonesia 46 di Palembang. Skripsi. Universitas Bengkulu.

Ermawati, Nanik. (2012). Pengaruh Partisipasi Anggaran Terhadap Kinerja Manajerial : Komitmen Organisasi dan Persepsi Inovasi Sebagai Variabel Intervening (Studi Kasus Pada SKPD Kabupaten Pati). Tesis. Universitas Diponegoro Semarang. DOI: 10.30659/jai.6.2.141-156

Ghozali, Imam. (2013). Aplikasi Analisis Multivariate dengan Program SPSS. Edisi 7. Semarang: Universitas Diponogoro.

Harsasto, Priyatno. (2013). Manajemen dan Pengukuran Kinerja Pemerintahan. E-jurnal. Universitas Diponegoro. DOI: https://doi.org/10.14710/politika.2.1.2011.18-31

Jannah Miftahul, Sri Rahayu. (2015). Pengaruh Partisipasi Penganggaran terhadap Kinerja Manajerial SKPD dengan Kejelasan Sasaran Anggaran, Komitmen Tujuan Anggaran, Keadilan Distributif dan Pengawasan Internal sebagai Variabel Intervening. Jurnal Perspektif Pembiayaan Dan Pembangunan Daerah, Volume 3 No.2 Oktober - Desember 2015. Retrieved from : https://onlinejournal.unja.ac.id/JES/article/view/3501

Medhayanti, Ni Putu. 2015. Pengaruh Partisipasi Anggaran terhadap Kinerja Manajerial dengan Self Efficacy, Desentralisasi, dan Budaya Organisasi sebagai Variabel Pemoderasi. E-jurnal Akuntansi Universitas Udayana, 11(1): h: 155-170. Retrieved from : https://ojs.unud.ac.id/index.php/Akuntansi/article/view/10436

Mia, L. (1998). Managerial Attitudes, Motivation and Effectiveness of Budget Participation. Journal Accounting Organizations and Society. 13(5), pp:465-475. Retrieved from : https://doi.org/10.1016/0361-3682(88)90017-7

Nasir, A., dan Oktari, R. (2013). Pengaruh Pemanfaatan Teknologi Informasi Dan Pengendalian Intern Terhadap Kinerja Instansi Pemerintah (Studi Pada Satuan Kerja Perangkat Daerah Kabupaten Kampar). Jurnal Ekonomi. 
Njeri, Kamau Caroline. (2014). Effect of Internal Controls on the Financial Performance of Manufacturing Firms in Kenya. Thesis. University of Nairobi.

Nursidin, M. 2008. Pengaruh Anggaran Partisipatif Terhadap Kinerja Manajerial Melalui Kesenjangan Anggaran dan Motivasi Kerja pada PT. (Persero) Pelabuhan Indonesia-Medan. Tesis. Sekolah Pasca Sarjana Universitas Sumatera Utara.

Putri, Gustika Yolanda. (2013). Pengaruh Komitmen Organisasi Dan Sistem Pengendalian Intren Pemerintah (SPIP) Terhadap Kinerja Manajerial SKPD (Studi Empiris pada Satuan Kerja Perangkat Daerah Kota Padang). Simposium Nasional Akuntansi. Universitas Negeri Padang. Retrieved from : http://ejournal.unp.ac.id/students/index.php/akt/article/view/119

Riyadi, S. (1998). Motivasi dan Pelimpahan Wewenang sebagai Variabel Moderating dalam Hubungan antara Pengaruh Partisipasi Penyusunan Anggaran dan Kinerja Manajerial. Tesis. Program Pascasarjana Universitas Gajah Mada.

Santoso, Eli Budi. (2016). Pengaruh Sistem Pengendalian Intern Pemerintah, Pemanfaatan Teknologi Informasi dan Kompetensi Sumber Daya Manusia terhadap Akuntabilitas Keuangan Daerah. Tesis. Universitas Lampung. Retrieved from : http://digilib.unila.ac.id/id/eprint/22224

Shodiq, M. J. (2001). Pengaruh Sistem Kontrol terhadap Kinerja Keuangan: Uji Fit Versus Uji Internal Consistency. Tesis. Universitas Diponegoro.

Tresnawati, Rina. (2012). Pengaruh Efektivitas Pengendalian Intern Terhadap Kinerja Instansi Daerah Pada Di Pendapatan Daerah Kota Bandung. Prosiding Seminar Nasional. Universitas Widyatama.

Trihapsoro, Argo \& Dr. Erma Setiawati, Ak, MM (2015). Pengaruh Kualitas Sumber Daya Manusia, Pemanfaatan Teknologi Informasi dan Sistem Pengendalian Intern Pemerintah terhadap Kinerja Pemerintah Daerah. Skripsi. Universitas Muhamadyah Surakarta. Retrieved from : http://eprints.ums.ac.id/id/eprint/39105

Wijaya, Widi Angga, Rina Arifati dan Agus Suprijanto. (2016). Analisis Pengaruh Independensi, Motivasi, Pengalaman Kerja, Profesionalisme, dan Gaya Kepemimpinan terhadap Efektivitas Penerapan Sistem Pengendalian Intern. Jurnal Akuntansi. Universitas Pandanaran Semarang. 2(2). Retrieved from : https://jurnal.unpand.ac.id/index.php/AKS/article/view/457

Yanti, Ni Wayan Mirda. 2016. Asimetri Informasi sebagai Pemoderasi Pengaruh Partisipasi Penganggaran dan Kejelasan Anggaran pada Senjangan Anggaran (Studi Empiris pada Satuan Kerja Perangkat Daerah Kabupaten Tabanan). E-Jurnal Akuntansi Universitas Udayana. 15(1): h: 257-285. Retrieved from : $\underline{\text { https://ojs.unud.ac.id/index.php/Akuntansi/article/view/16135 }}$

www.denpasar.bpk.go.id 